\title{
POLA KAJIAN HADIS AKADEMIK \\ DI PERGURUAN TINGGI KEAGAMAAN ISLAM NEGERI \\ (PTKIN) DI INDONESIA (Studi Skripsi Mahasiswa Tafsir Hadis UIN Raden Fatah \\ Palembang, UIN Syarif Kasim Pekanbaru dan UIN Imam Bonjol Padang)
}

\author{
Adriansyah. NZ \\ Universitas Islam Negeri Raden Fatah Palembang \\ adriansyah uin@radenfatah.ac.id
}

\begin{abstract}
The study of hadith at the Indonesian Islamic College (PTAI) has a pattern, variety and characteristics in accordance with their respective characteristics. The various types and forms of courses offered in the study of hadith indicate a continuous dynamic. The Department of Interpretation of the Hadith of Raden Fatah UIN in Palembang, UIN Syarif Kasim Pekanbaru and UIN Imam Bonjol Padang in the field of Hadith Science, took refuge, which has resulted in many alumni. Ideally their works are disseminated to the public in order to obtain positive impact on religious life. The reality is not the case, to this day no one has seriously searched through research. This research is important to know the pattern and typical study of academic hadith that develops on students of the interpretation of hadith, especially the study program of Hadith at UIN Raden Fatah Palembang, UIN Syarif Kasim Pekanbaru and UIN Imam Bonjol Padang and provide adequate contributions in the development of hadith studies in Indonesia. So far, the most dominant model of hadith study in thesis writing of the student of UIN Raden Fatah Palembang and UIN Imam Bonjol Padang is hadith fiqh. While UIN Syarif Kasim Pekanbaru is more inclined towards the criticism of hadith (naqd al-hadith). Theme of the thesis study most in demand by students of the Raden Fatah UIN Palembang and UIN Imam Bonjol is a matter of shari'a, in contrast to UIN Syarif Kasim Pekanbaru, it is more inclined to the theme of the traditions of worship. The methodology of the study of academic hadith studies used by students in conducting hadith research is textual, intertextual and contextual.
\end{abstract}

Keywords: Pattern, Academic Hadith, UIN Raden Fatah Palembang, UIN Syarif Kasim Pekanbaru, UIN Imam Bonjol Padang

\section{Abstrak}

Studi hadis di Perguruan Tinggi Agama Islam (PTAI) Indonesia memiliki pola, ragam dan karakteristik sesuai dengan kekhasan masing-masing. Berbagai jenis dan bentuk mata kuliah yang ditawarkan dalam studi hadis menandakan adanya dinamika yang berkesinambungan. Program Studi IImu Hadis di UIN Raden Fatah Palembang, UIN Syarif Kasim Pekanbaru dan UIN Imam Bonjol Padangtelah mengasilkan banyak Alumni. Secara ideal, hasil penelitian para alumni tersebut didiseminasikan kepada khalayak agar memberikan dampak yang positif bagi kehidupan keagamaan. Akan tetapi, hal ini tidak terealisasi karena hingga hari ini 
belum ada yang melakukan penelusuran secara serius melalui penelitian. Penelitian ini menjadi penting untuk mengetahui pola dan tipikal kajian hadis akademik yang berkembang pada mahasiswa IImu Hadis, terutama prodi IImu Hadis di UIN Raden Fatah Palembang, UIN Syarif Kasim Pekanbaru dan UIN Imam Bonjol Padang serta memberikan kontribusi yang memadai dalam pengembangan kajian hadis di Indonesia. Sejauh ini, model kajian hadis yang paling dominan dalam penulisan skripsi mahasiswa cenderung variatif, antara lain UIN Raden Fatah Palembang dan UIN Imam Bonjol Padang yang cenderung padafigh hadis dan UIN Syarif Kasim Pekanbaru pada kritik hadis (naqd al-hadis).Tema kajian skripsi yang paling diminati oleh mahasiswa UIN Raden Fatah Palembang dan UIN Imam Bonjol adalah masalah syari'ah, berbeda dengan UIN Syarif Kasim Pekanbaru, lebih cenderung pada tema hadis-hadis ibadah. Adapun metodologi kajian kajian hadis akademik yang digunakan para mahasiswa dalam melakukan penelitian hadis adalah tekstual, intertekstual dan kontekstual.

Kata Kunci: Pola, Hadis Akademik, UIN Raden Fatah Palembang, UIN Syarif Kasim Pekanbaru, UIN Imam Bonjol Padang

\section{A. Pendahuluan}

Hadis Nabi Saw menduduki posisi strategis dalam Islam sebagai salah satu sumber utama ajaran Islam ${ }^{1}$.Pernyataan ini tidak hanya diakui oleh para ulama hadis klasik, namun juga diakui oleh ulama hadis kontemporer.Hal inilah yang kemudian menjadikan diskursus seputar pemahaman hadis tidak pernah mengenal kata usai.Selama ini, hadis telah dikaji dengan beragam metode dan diajarkan dengan aneka ragam.Perkembangan diskursus seputar pemahaman hadis ini tidak juga terjadi di dunia Islam semata, bahkan juga mengundang perhatian di kalangan dunia Barat.

Perkembangan selanjutnya, diskursus kajian hadis ini juga melibatkan kalangan akademik di Perguruan Tinggi Agama Islam yang telah menghasil banyak karya hadis dari berbagai model, karakteristik dan lahan kajian.Karya kajian hadis yang telah dihasilkan dari kegiatan akademik ini bisa disebut dengan hadis akademik.Studi hadis di Perguruan Tinggi Agama Islam (PTAI) Indonesia memiliki pola, ragam dan karakteristik sesuai dengan kekhasan masing-masing. Berbagai jenis dan bentuk mata kuliah yang tawarkan dalam studi hadis menandakan adanya dinamika yang berkesinambungan. Studi hadis tidak identik dengan ilmu hadis atau hadis, akan tetapi studi ini sudah mengikuti arus perkembangan dan tuntutan zaman dimana arus teknologi yang menghasilkan adanya transformasi ilmu pengetahuan ke

\footnotetext{
${ }^{1}$ Sisi fungsinya terhadap al-Qur'an, hadis berperan sebagai Bayan al-Taqrir (keterangan penegas), Bayan al-Tafsir (keterangan penjelas) bagi kandungan al-Qur'an dan bahkan sebagai Bayan al-Tasyri' (membuat hukum baru) bagi masalah-masalah yang tidak tertuang dalam al-Qur'an. Fungsi-fungsi hadis tersebut disepakati oleh para ulam. Tetapi di samping tiga fungsi itu, terdapat satu fungsi yang diperselisihkan oleh para ulama, yaitu hadis sebagai Bayan al-Nasakh (keterangan penghapus) bagi hukum yang terdapat dalam al-Qur'an. Di antara ulama yang mendukung fungsi ini antara lain ulama Hanafiyah, Mu'tazilah dan Ibn Hazm al-Zhahiri. Sementara itu, ulama yang menolak diantaranya adalah mayoritas al-Syafi'iyyah, dan Zhahiriyyah. Lebih lanjut lihat: 'Abbas Mutawalli Hamadah, al-Sunnah al-Nabawiyyah wa Makanatuha fi Tasyri', (Kairo: Dar alQaumiyyah: 1965), h. $169-173$
} 
berbagai belahan dunia menyebabkan pemahaman yang segar terhadap kajian hadis ${ }^{2}$.

Sebagai salah satu institusi pendidikan tinggi agama Islam, PTKIN (UIN/IAIN/STAIN) memiliki peranan yang penting dalam mengembangkan kajiankajian sumber ajaran Islam secara mendalam dan ilmiah.Harapan ini wajar disandarkan kepada PTKIN karena di lembaga inilah kegiatan ilmiah dapat tumbuh dengan baik dan subur dibandingkan dengan habitat dan lingkungan pendidikan lainnya.

UIN Raden Fatah Palembang, UIN Imam Bonjol Padang dan UIN Syarif Kasim merupakan salah satu Perguruan Tinggi Negeri dalam menyelenggarakan kajian keislaman, terutama pada studi hadis. Skripsi-skripsi hadis mahasiswa yang telah dihasilkan akan mencerminkan arah kajian hadis di masing-masing perguruan tinggi keagamaan di Indonesia.

Idealnya karya-karya mahasiswa tersebut didiseminasikan kepada khalayak agar memberikan dampak yang positif bagi kehidupan keagamaan. Realitanya tidak demikian, hingga hari ini belum ada yang melakukan penelusuran secara serius melalui penelitian. Penelitian ini menjadi penting untuk mengetahui pola dan tipikal kajian hadis akademik yang berkembang pada mahasiswa Tafsir Hadis, terutama di UIN Raden Fatah Palembang, UIN Imam Bonjol Padang dan UIN Syarif Kasim Pekanbaru serta memberikan kontribusi yang memadai dalam pengembangan kajian hadis di Indonesia. Alasan pemilihan tiga perguruan ini (UIN Raden Fatah Palembang, UIN Imam Bonjol Padang dan UIN Syarif Kasim) dalam menentukan kajian hadis akademik adalah merupakan perguruan tinggi yang cukup banyak menghasilkan karya hadis dan perguruan tinggi yang cukup diperhitungkan dalam wilayah Sumatera.Maka atas dasar inilah alasan penulis tertarik untuk mengangkat tema ini dalam bentuk penelitian, terutama mengenai pola kajian hadis akademik yang dilakukan mahasiswa Tafsir hadis berupa hasil karya skripsi mereka.

\section{B. Model Penelitian Hadis}

Setidaknya ada enam hal yang melatarbelakangi urgensi penelitian hadis ${ }^{3}$.Pertama, hadis sebagai sumber hukum Islam yang kedua setelah al-Quran, hadis Nabi memiliki karakter yang berbeda dari al-Quran.Al-Quran, seluruh riwayatnya mutawatir ${ }^{4}$, sedangkan hadis ada kalanya diriwayatkan secara mutawatir ada pula yang $\mathrm{ahad}^{5}$.Oleh karena itu, al-Quran dari sisi periwayatannya memiliki kedudukan yang qath'i al-tsubut (kebenaran beritanya absolut).Berbeda dengan hadis yang ada kalanya qat'i dan adakalanya bahkan banyak yang dzanni al-tsubut (kebenaran beritanya relatif dan nisbi).Maka dari itu, dapat dikatakan bahwa seluruh

2 Alfatih Suryadilaga, Ragam Studi Hadis di PTKIN Indonesia dan Karakteristinya: Studi atas Kurikulum IAIN Bukittinggi, IAIN Batu Sangkar, UIN Suna Kalijaga dan IAIN Jember, (Jakarta: JJournal of Qur'an and Hadits,: 2015), h. 217

${ }^{3}$ Muhammad Syuhudi Ismail, Metodologi Penelitian Hadis Nabi, (Jakarta: Bulan Bintang: 199, h. 23

${ }^{4}$ Hadis mutawatir adalah hadis yang diriwayatkan oleh sekelompok rawiy yang mustahil bagi mereka untuk berdusta dari awal sanad sampai akhirnya, dan hendaknya tidak ada kesendirian pada kelompok ini meskipun pada salah satu tingkatan sanadnya. Lihat Muhammad 'Ajjaj al-Khatib, Ushul al-Hadis; 'Ulumuh wa Musthalahuh, (Beirut: Dar al-Fikr,1409 H / 1989 M), h. 301 dan lihat juga Musthafa al-Siba'iy, al-Sunnah wa Makanatuha fiy al-Tasyri' al-Islamiy, (Kairo: Maktabah Dar al-'Arubah, 1380 H/1961 M), Cetakan Pertama, h. 150

${ }^{5}$ Hadis ahad adalah hadis yang diriwayatkan seorang, dua orang rawiy atau lebih, dimana jumlah mereka itu belum mencapai tingkat masyhur atau mutawatir, dan tidak ada standar jumlah pada tingkatan sesudahnya baik berbentuk mutawatir dan masyhur. Lihat al-Khatib, Ushul al-Hadis, op.cit, h. 302 
ayat al-Quran tidak perlu diteliti orisinalitas periwayatannya, sedangkan hadis Nabi, lebih-lebih yang berkategori ahad, perlu dikaji dan diteliti orisinalitasnya.Sehingga dapat diketahui apakah hadis tersebut dapat dipertanggungjawabkan periwayatannya dari Nabi atau tidak.

Kedua, seperti yang lazim diketahui, tidak semua hadis telah tertulis pada zaman Nabi Saw. Mengingat akan setiap hadis tidak selalu terjadi di hadapan orang banyak. Selain itu, tidak setiap hadis yang telah ditulis para sahabat telah di crosscheck di hadapan Nabi.Hal ini berimplikasi bahwa hadis Nabi tidak lah terhindar dari kemungkinan adanya kesalahan periwayatan.

Ketiga, timbulnya pemalsuan hadis.Gerakan pemalsuan hadis ini mulai muncul pada tahun 40-an H. pada masa khalifah Ali Bin Abi Tahlib.Pada mulanya, pemalsuan ini didorong oleh kepentingan politik. Terutama ketika terjadi pertentangan politik antara Ali dan Mu`awiyah. Akan tetapi kemudian merembet tidak hanya pada faktor politik, melainkan juga kepentingan ekonomi, menjilat pejabat dan lain sebagainya turut andil dalam meramaikan gerakan pemalsuan hadis. Dengan adanya pemalsuan hadis, akan sulit sekali memisahkan mana yang benar-benar berasal dari Nabi dan mana yang bukan. Di sinilah letak mengapa penelitian ini urgen dilakukan.

Keempat, lamanya proses penghimpunan hadis. Penghimpunan hadis secara resmi dan massal terjadi pada masa khalifah Umar Bin Abdul Aziz yang wafat pada tahun $101 \mathrm{H}$. Dikatakan resmi karena penghimpunan itu atas prakarsa dan kebijaksanaan kepala negara.Dan massal karena kebijaksanaan tersebut ditujukan kepada para gubernur dan ulama hadis pada zaman itu. Kemudian pada pertengahan abad ke 2 Hijriah muncul karya-karya himpunan hadis di beberapa kota besar; Makah, Madinah, Basrah. Dan puncak penghimpunan Hadis ini terjadi sekitar pertengahan abad ke 3 Hijriah.

Dengan demikian, penulisan kitab-kitab hadis yang menjadi rujukan kaum muslimin itu ditulis jauh setelah Nabi wafat. Dalam rentang waktu antara penulisan dan wafatnya Nabi, tidak menutup kemungkinan adanya hal-hal yang menjadikan riwayat itu tidak sesuai dengan apa yang datang dari Nabi. Untuk itulah, perlu adanya penelitian untuk mengetahui apakah hadis itu sah digunakan sebagai hujjah ataukah tidak.

Kelima, jumlah kitab hadis yang banyak dengan metode penyusunan yang berbeda-beda.Kitab hadis yang dihasilkan ulama sangat banyak hal ini ditengarai karena jumlah mukharrij al-hadis yang juga banyak jumlahnya.Selain itu, ada pula seorang penghimpun hadis yang menghasilkan kitab himpunan hadis lebih dari satu.Metode penyusunan kitab-kitab tersebut tidaklah seragam, hal ini merupakan hal yang lumrah mengingat penekanan penulisan tersebut terletak pada pengumpulan dan penghimpunan hadis, bukan pada penyusunannya.Melihat kenyataan tersebut, maka kualitas hadis yang ada di dalam kitab-kitab hadis tidak semuanya sama. Maka dari itu, perlu diadakan penelitian untuk mengetahui mana yang dapat dijadikan hujjah dan mana yang tidak.

Terakhir, adanya periwayatan hadis secara makna.Para sahabat pada umumnya membolehkan periwayatan hadis secara makna.Ini menunjukkan bahwa periwayatan hadis secara makna telah ada.Padahal, untuk mengetahui kandungan petunjuk hadis tertentu perlu mengetahui redaksi tekstual dari hadis yang bersangkutan terutama yang berupa sabda/ucapan Nabi.Berdasarkan latar belakang sejarah periwayatan hadis di atas, maka ada dua bagian hadis yang menjadi objek kajian dalam metodologi penelitian hadis agar sebuah hadis dapat dipertanggungjawabkan orisionalitas dan validitasnya.Kedua bagian tersebut adalah 
sanad hadis dan matan hadis.Yang pertama terkait dengan rangkaian periwayat yang menyampaikan hadis, sedangkan yang kedua berkaitan dengan materi atau isi dari pada hadis tersebut.

Model-model penelitian hadis secara umum dapat diklasifikasikan dalam lima kategori, yaitu penelitian tentang mushthalah al-hadis, naqd al-hadis, fiqh al-hadis, kajian kitab dan pemikiran atau tokoh. Hanya saja penelitian fiqh al-hadis tidak dapat dilepaskan dari penelitian naqd al-hadis, tetapi tidak sebaliknya. Meskipun demikian, fiqh al-hadis dipisahkan dari naqd al-hadis karena sebagian penelitian hadis memfokuskan pada naqd al-hadis semata tanpa melibatkan figh al-hadis di dalamnya. Untuk lebih memahami kelima kategori penelitian hadis tersebut, berikut cara dan langkah-langkahnya masing-masing.

\section{Eksistensi Prodi Ilmu Hadis di Pangkalan Data Perguruan Tinggi (PDPT) DIKTI}

Sejak tahun 2015/2016 seiring dengan adanya regulasi perkembangan di Kementerian Agama Republik Indonesia dan adanya perubahan nomenklatur keilmuan di Kementerian Agama, berdasarkan Surat Keputusan Direktur Jenderal Nomor 4979 tahun 2014 tertanggal 05 September 2014, Jurusan Tafsir Hadis kini dipecah menjadi dua jurusan/prodi, yaitu jurusan/prodi IImu al-Qur'an dan Tafsir (IAT/IQT) dan jurusan/prodi IImu Hadis (ILHA). Sampai tahun akademik 2015/2016, jurusan/prodi IImu Hadis di PTKIN berjumlah 16 jurusan/prodi, sementara yang hanya membuka jurusan/prodi IImu al-Qur'an dan Tafsir berjumlah 32 jurusan/prodi dan masih dalam bentuk format lama yaitu Jurusan Tafsir Hadis ada 9 jurusan di PTKIN.

Berdasarkan informasi dari Keputusan Menteri Agama Nomor 124 tahun 2015 tentang besaran UKT, maka PTKIN yang membuka jurusan/prodi IImu Hadis, IImu alQur'an dan Tafsir dan Tafsir Hadis adalah sebanyak 16 PTKIN diantaranya adalah; UIN Alaudin Makasar, UIN Sunan Ampel Surabaya, UIN Sunan Kalijaga Yogyakarta, UIN Sumatera Utara Medan, IAIN Bengkulu, IAIN Bikit Tinggi Sumatera Barat, IAIN Jember, IAIN Raden Intan Lampung, IAIN Salatiga (Ushuluddin Adab dan Humaniora), IAIN Sultan Amai Gorontalo (Ushuluddin dan Dakwah), IAIN Banten, STAIN Kudus (Ushuluddin), STAIN Kediri (Ushuluddin), IAIN Batusangkar Sumatera Barat (Syariah dan Ekonomi Islam), dan IAIN Sjek Nurjati Cirebon (Ushuluddin, Adab dan Dakwah).

Beberapa PTKIN masih menggunakan tradisi lama yaitu Tafsir Hadis sebanyak 9 PTKIN antara lain; UIN Raden Fatah Palembang, UIN Sultan Syarif Qasim Riau, UIN Sunan Gunung Djati Bandung, UIN Syarif Hidayatullah Jakarta, IAIN Surakarta, IAIN Jambi, STAIN Pekalongan (Ushuluddin), dan STAIN Ponorogo (Ushuluddin dan Dakwah). Sementara beberapa PTKIN hanya membuka prodi IAT/IQT saja dan tidak membuka prodi IImu Hadis, diantaranya adalah: UIN arRaniry Aceh, IAIN Kendari, IAIN Langsa Aceh, IAIN Manado, IAIN Mataram, IAIN Samarinda, IAIN Palangkaraya, IAIN Palopo, IAIN Patimura, IAIN Purwokerto, IAIN Tulung Agung, dan IAIN Ternate.

Data diatas telah terjadi perubahan, karena ada beberapa perguruan tinggi telah membuka prodi IImu Hadis yang telah dikeluarkan oleh Direktur Jenderal Pendidikan Islam. Data terakhir yang penulis temui pada Pangkalan Data Perguruan Tinggi (PDPT) DIKTI, ditemukan sebanyak 32 jurusan/prodi Ilmu Hadis dari berbagai perguruan Tinggi Agama Islam Negeri di Indonesia. Berikut rincian prodi IImu Hadis dari berbagai PTKIN di Indonesia: 


\begin{tabular}{|c|c|c|c|c|}
\hline No. & $\begin{array}{l}\text { Kode } \\
\text { Prodi } \\
\end{array}$ & Nama Prodi & Jenjang & Perguruan Tinggi \\
\hline 1 & 76235 & IImu Hadis & S1 & STAIN Zawiyah Cot Kala Langsa \\
\hline 2 & 76235 & IImu Hadist & $S 1$ & IAIN Kendari \\
\hline 3 & 76235 & IImu Hadis & S1 & $\begin{array}{l}\text { Universitas Islam Negeri Sunan } \\
\text { Kalijaga }\end{array}$ \\
\hline 4 & 76235 & Imu Hadis & S1 & IAIN Bukittinggi \\
\hline 5 & 76235 & IImu Hadis & S1 & $\begin{array}{l}\text { Universitas Islam Negeri Raden Fatah } \\
\text { Palembang }\end{array}$ \\
\hline 6 & 76235 & Imu Hadist & S1 & STAIN Sultan Qaimuddin Kendari \\
\hline 7 & 76235 & IImu Hadis & S1 1 & $\begin{array}{l}\text { Sekolah Tinggi Ilmu Ushuluddin } \\
\text { Darussalam, Bangkalan, Jawa Timur }\end{array}$ \\
\hline 8 & 76235 & IImu Hadis & S1 & $\begin{array}{l}\text { IAIN Sultan Maulana Hasanuddin } \\
\text { Banten }\end{array}$ \\
\hline 9 & 76235 & IImu Hadis & S1 & $\begin{array}{l}\text { Universitas Islam Negeri Syarif } \\
\text { Hidayatullah }\end{array}$ \\
\hline 10 & 76235 & Ilmu Hadis & S1 & IAIN Salatiga \\
\hline 11 & 76235 & IImu Hadist & S1 & IAIN Bengkulu \\
\hline 12 & 76235 & Ilmu Hadis & S1 & STAIN Jember \\
\hline 13 & 76235 & IImu Hadis & S1 & $\begin{array}{l}\text { Sekolah Tinggi Ilmu Al-Qur'an Al- } \\
\text { Lathifiyyah Palembang Sumatera } \\
\text { Selatan }\end{array}$ \\
\hline 14 & 76235 & Imu Hadis & S1 & IAIN Langsa \\
\hline 15 & 76235 & IImu Hadis & S1 & IAIN Syekh Nurjati Cirebon \\
\hline 16 & 76235 & Ilmu Hadis & S1 & STAIN Pekalongan \\
\hline 17 & 76235 & IImu Hadis & S1 & $\begin{array}{l}\text { STAIN Sjech M. Djamil Djambek } \\
\text { Bukittinggi }\end{array}$ \\
\hline 18 & 76235 & Imu Hadis & S1 & IAIN Raden Fatah Palembang \\
\hline 19 & 76235 & IImu Hadis & S1 1 & $\begin{array}{l}\text { Institut Agama Islam (IAI) Bani Fattah } \\
\text { Jombang }\end{array}$ \\
\hline 20 & 76235 & Imu Hadis & S1 & Universitas Islam Negeri Alauddin \\
\hline 21 & 76235 & IImu Hadis & S1 & $\begin{array}{l}\text { STAI Balaiselasa YPPTI Pesisir } \\
\text { Selatan, Sumatera Barat }\end{array}$ \\
\hline 22 & 76235 & Imu Hadis & $S 1$ & STAIN Kudus \\
\hline 23 & 76235 & IImu Hadis & S1 & IAIN Sultan Amai Gorontalo \\
\hline 24 & 76235 & Imu Hadist & $S 1$ & Universitas Islam Negeri Sunan Ampel \\
\hline 25 & 76235 & IImu Hadis & S1 & $\begin{array}{l}\text { Universitas Islam Negeri Sunan } \\
\text { Gunung Jati }\end{array}$ \\
\hline 26 & 76235 & Imu Hadis & S1 & STAIN Batusangkar \\
\hline 27 & 76235 & Imu Hadis & S1 & IAIN Jember \\
\hline 28 & 76235 & Imu Hadist & S1 & IAIN Imam Bonjol Padang \\
\hline
\end{tabular}




\begin{tabular}{|c|c|c|c|c|}
\hline & & (Tafsir Hadis) & & \\
\hline 29 & 76235 & IImu Hadis & S1 & $\begin{array}{l}\text { Universitas Islam Negeri Sulthan Syarif } \\
\text { Kasim }\end{array}$ \\
\hline 30 & 76235 & IImu Hadis & S1 & $\begin{array}{l}\text { Sekolah Tinggi Islam Bani Fatah } \\
\text { Tambakberas Jombang }\end{array}$ \\
\hline 31 & 76235 & IIImu Hadist & S1 & IAIN Sunan Amnel \\
\hline 32 & 76235 & Imu Hadis & S1 & $\begin{array}{l}\text { Sekolah Tinggi Ilmu Al-Qur'an (STIQ) } \\
\text { An-Nur Yogyakarta }\end{array}$ \\
\hline
\end{tabular}

\section{Ilmu Hadis di Tiga Perguruan Tinggi}

Tiga Perguruan Tinggi Keagamaan Agama Islam Negeri, yaitu UIN Raden Fatah Palembang, UIN Syarif Kasim Pekanbaru dan UIN Imam Bonjol Padang sudah banyak meluluskan alumni dan karya ilmiah berupa skripsi, terutama alumni Tafsir Hadis (termasuk IImu Hadis). Tercatat bahwa, alumni Tafsir Hadis UIN Raden Fatah Palembang berjumlah 481 mahasiswa dengan 481 Skripsi, 143 mahasiswa yang menulis skripsi dalam kajian hadis. UIN Syarif Kasim Pekanbaru telah meluluskan 401 alumni dengan 401 skripsi, 123 diantaranya menulis skripsi kajian hadis dan UIN Imam Bonjol Padang telah meluluskan 320 mahasiswa dengan 320 skripsi, 99 skripsi diantaranya mengkaji hadis.

\section{Model Kajian Hadis Akademik UIN Raden Fatah Palembang, UIN Syarif Kasim Pekanbaru dan UIN Imam Bonjol Padang}

Pada bab terdahulu sudah penulis jelaskan, bahwa model-model penelitian hadis dapat diklasifikasikan dalam 5 kategori, yaitu penelitian tentang mushthalah alhadis, naqd al-hadis, figh al-hadis, kajian kitab hadis dan pemikiran/tokoh hadis. Bila dilakukan analisis terhadap isi (content) pembahasan, maka skripsi di bidang hadis dari tiga perguruan tinggi Islam negeri ini dengan rincian sebagai berikut:

Model Kajian Hadis UIN Raden Fatah Palembang

\begin{tabular}{|l|l|c|c|c|c|c|c|}
\hline \multirow{2}{*}{ No } & \multirow{2}{*}{ Tahun } & Jumlah & \multicolumn{5}{|c|}{ Model Kajian } \\
\cline { 4 - 8 } & & Skripsi & Mushthalah & Naqd & Fiqih & Kitab & Tokoh \\
\hline 1 & 1995 & 3 & 3 & - & - & - & - \\
\hline 2 & 1996 & 6 & 1 & 2 & 1 & - & 2 \\
\hline 3 & 1997 & 7 & 4 & - & 3 & - & - \\
\hline 4 & 1998 & 3 & 1 & & 1 & & 1 \\
\hline 5 & 1999 & 9 & 3 & 2 & 3 & - & 1 \\
\hline 6 & 2000 & 7 & 1 & - & 4 & - & 2 \\
\hline 7 & 2001 & 2 & - & - & 2 & - & - \\
\hline 8 & 2002 & 5 & - & 2 & 2 & - & 1 \\
\hline 9 & 2003 & 9 & - & 5 & 3 & - & 1 \\
\hline 10 & 2004 & 12 & - & 10 & 2 & - & - \\
\hline 11 & 2005 & 5 & - & 2 & 3 & - & - \\
\hline
\end{tabular}




\begin{tabular}{|l|l|c|c|c|c|c|c|}
\hline 12 & 2006 & 2 & 1 & 1 & - & - & - \\
\hline 13 & 2007 & 4 & - & 2 & - & - & 2 \\
\hline 14 & 2008 & 6 & 2 & 1 & 2 & - & 1 \\
\hline 15 & 2009 & 6 & 3 & - & 3 & - & - \\
\hline 16 & 2010 & 1 & - & - & 1 & - & - \\
\hline 17 & 2011 & 10 & 1 & - & 7 & - & 2 \\
\hline 18 & 2012 & 13 & - & 2 & 6 & 5 & - \\
\hline 19 & 2013 & 13 & 1 & - & 9 & 2 & 1 \\
\hline 20 & 2014 & 5 & 1 & - & 1 & 2 & 1 \\
\hline 21 & 2015 & 9 & - & - & 7 & 2 & - \\
\hline 22 & 2016 & 6 & - & - & 4 & 1 & 1 \\
\hline \multicolumn{2}{|l|}{ Jumlah } & 143 & 22 & 29 & 64 & 12 & 16 \\
\hline
\end{tabular}

Berdasarkan gambaran bagan diatas, jika dilakukan analisis terhadap isi (kontent) pembahasan, maka skripsi di bidang hadis dan ilmunya dapat diklasifikasikan dalam 5 bagian ilmu, yaitu ilmu mushthalah hadis, penelitian (naqd) hadis, pemahaman (figh) hadis, kajian kitab hadis dan pemikiran atau tokoh hadis. Dari kelima bidang tersebut ditemukan bahwa sejak tahun 1995 sampai tahun 2016 jumlah skripsi yang dapat ditemukan adalah 143 buah, dengan rincian 22 skripsi yang memfokuskan kajiannya pada ilmu mushthalah hadis, 29 skripsi yang mengkaji naqd hadis, 64 skripsi merupakan hasil pengkajian figh hadis, 12 skripsi membahas tentang kitab hadis dan 16 skripsi yang menfokuskan pada pemikiran atau tokoh hadis.

Berdasarkan gambaran diatas, terlihat bahwa tema skripsi yang paling banyak diminati adalah naqd hadis dan figh hadis. Pada hakikatnya, kajian fiqh hadis tidak dapat dilepaskan dari naqd hadis. Hal tersebut terjadi karena dalam kajian teks hadis, seorang peneliti tidak diperkenankan melakukan penelitian teks hadis tanpa memastikan terlebih dahulu kualitas hadis yang ingin dikaji. Oleh sebab itu, penelitian fiqh hadis menjadi dominan dan mendapat tempat lebih dari penelitian mahasiswa yang mengkaji dalam bidang hadis.

Model Kajian Hadis UIN Syarif Kasim Pekanbaru

\begin{tabular}{|l|l|l|l|l|l|c|c|}
\hline \multirow{2}{*}{ No } & \multirow{2}{*}{ Tahun } & Jumlah & \multicolumn{6}{|c|}{ Model Kajian } \\
\cline { 5 - 8 } & & Skripsi & Mushthalah & Naqd & Fiqih & Kitab & Tokoh \\
\hline 1 & 1995 & 1 & - & - & - & - & 1 \\
\hline 2 & 1996 & 5 & 4 & 1 & - & - & \\
\hline 3 & 1997 & 10 & 4 & 1 & 1 & - & 4 \\
\hline 4 & 1998 & 5 & 2 & 1 & - & - & 2 \\
\hline 5 & 1999 & 7 & 2 & 4 & 1 & - & - \\
\hline 6 & 2000 & 8 & 1 & 5 & - & - & 2 \\
\hline 7 & 2001 & 3 & 1 & 1 & - & - & 1 \\
\hline 8 & 2002 & 1 & 1 & - & - & - & - \\
\hline 9 & 2003 & 4 & - & 4 & - & - & - \\
\hline 10 & 2004 & 6 & - & 5 & - & - & 1 \\
\hline 11 & 2005 & 5 & - & 2 & 3 & - & - \\
\hline 12 & 2006 & 2 & - & 2 & - & - & - \\
\hline 13 & 2008 & 4 & - & 1 & 2 & - & 1 \\
\hline 14 & 2009 & 2 & - & 2 & - & - & - \\
\hline 15 & 2010 & 4 & - & 4 & - & - & - \\
\hline
\end{tabular}




\begin{tabular}{|l|l|c|c|c|c|c|c|}
\hline 16 & 2011 & 1 & - & 1 & - & - & - \\
\hline 17 & 2012 & 10 & - & 3 & 6 & - & 1 \\
\hline 18 & 2013 & 11 & - & 4 & 6 & - & 1 \\
\hline 19 & 2014 & 11 & 1 & 2 & 6 & 1 & 1 \\
\hline 20 & 2015 & 23 & - & 9 & 12 & & 2 \\
\hline
\end{tabular}

Berdasarkan tabel diatas, maka jumlah skripsi yang dapat ditemukan adalah 123 buah, dengan rincian 16 skripsi yang memfokuskan kajiannya pada ilmu mushthalah hadis, 52 skripsi yang mengkaji naqd hadis, 37 skripsi merupakan hasil pengkajian fiqh hadis, 1 skripsi membahas tentang kitab hadis dan 17 skripsi yang menfokuskan pada pemikiran atau tokoh hadis.

Berdasarkan gambaran diatas, terlihat bahwa tema skripsi yang paling banyak diminati adalah naqd hadis dan figh hadis. Pada hakikatnya, kajian fiqh hadis tidak dapat dilepaskan dari naqd hadis. Hal tersebut terjadi karena dalam kajian teks hadis, seorang peneliti tidak diperkenankan melakukan penelitian teks hadis tanpa memastikan terlebih dahulu kualitas hadis yang ingin dikaji. Oleh sebab itu, penelitian fiqh hadis menjadi dominan dan mendapat tempat lebih dari penelitian mahasiswa yang mengkaji dalam bidang hadis

Model Kajian Hadis UIN Imam Bonjol Padang

\begin{tabular}{|l|l|l|c|c|c|c|c|}
\hline \multirow{2}{*}{ No } & \multirow{2}{*}{ Tahun } & \multirow{2}{*}{\begin{tabular}{l} 
Jumlah \\
\cline { 4 - 8 }
\end{tabular}} & & \multicolumn{6}{|c|}{ Model Kajian } \\
\cline { 5 - 8 } & 1993 & 2 & Mushthalah & Naqd & Fiqih & Kitab & Tokoh \\
\hline 2 & 1994 & 5 & 1 & - & 1 & - & - \\
\hline 3 & 1995 & 5 & 1 & 2 & 2 & - & - \\
\hline 4 & 1996 & 2 & 1 & - & 1 & - & - \\
\hline 5 & 2000 & 6 & 1 & 1 & 4 & - & - \\
\hline 6 & 2001 & 9 & 3 & 1 & 4 & - & 1 \\
\hline 7 & 2002 & 4 & - & - & 4 & - & - \\
\hline 8 & 2003 & 11 & 4 & - & 6 & - & 1 \\
\hline 9 & 2004 & 5 & - & 2 & 3 & - & - \\
\hline 10 & 2005 & 3 & - & - & 3 & - & - \\
\hline 11 & 2006 & 1 & - & - & 1 & - & - \\
\hline 12 & 2007 & 5 & - & 1 & 4 & - & - \\
\hline 13 & 2008 & 3 & - & - & 3 & - & - \\
\hline 14 & 2009 & 3 & - & - & 3 & - & - \\
\hline 15 & 2011 & 2 & - & - & 1 & - & 1 \\
\hline 16 & 2012 & 3 & - & 1 & 2 & - & - \\
\hline 17 & 2014 & 13 & 1 & - & 12 & - & - \\
\hline 18 & 2015 & 9 & 2 & - & 7 & - & - \\
\hline 19 & 2016 & 6 & - & - & 6 & - & - \\
\hline 20 & 2017 & 2 & - & - & 1 & 1 & - \\
\hline Jumlah & 99 & 16 & 9 & 69 & 1 & 4 \\
\hline
\end{tabular}

Jumlah skripsi yang dapat ditemukan dalam kajian hadis di UIN Imam Bonjol Padang adalah 99 buah, dengan rincian 16 skripsi yang memfokuskan kajiannya pada ilmu mushthalah hadis, 9 skripsi yang mengkaji naqd hadis, 69 skripsi 
merupakan hasil pengkajian figh hadis, 1 skripsi membahas tentang kitab hadis dan 4 skripsi yang menfokuskan pada pemikiran atau tokoh hadis.

Berdasarkan gambaran diatas, terlihat bahwa tema skripsi yang paling banyak diminati adalah mushthalah hadis dan figh hadis. Pada hakikatnya, kajian fiqh hadis tidak dapat dilepaskan dari mushthalah hadis. Hal tersebut terjadi karena dalam kajian teks hadis, seorang peneliti tidak diperkenankan melakukan penelitian teks hadis tanpa memastikan terlebih dahulu kualitas hadis yang ingin dikaji. Oleh sebab itu, penelitian figh hadis menjadi dominan dan mendapat tempat lebih dari penelitian mahasiswa yang mengkaji dalam bidang hadis

Berdasarkan gambaran bagan diatas, jika dilakukan analisis terhadap isi (kontent) pembahasan, maka skripsi di bidang hadis dan ilmunya dapat diklasifikasikan dalam 5 bagian ilmu, yaitu ilmu mushthalah hadis, penelitian (naqd) hadis, pemahaman (figh) hadis, kajian kitab hadis dan pemikiran atau tokoh hadis. Dari kelima bidang tersebut ditemukan bahwa sejak tahun 1995 sampai tahun 2016 jumlah skripsi yang dapat ditemukan adalah 143 buah, dengan rincian 22 skripsi yang memfokuskan kajiannya pada ilmu mushthalah hadis, 29 skripsi yang mengkaji naqd hadis, 64 skripsi merupakan hasil pengkajian fiqh hadis, 12 skripsi membahas tentang kitab hadis dan 16 skripsi yang menfokuskan pada pemikiran atau tokoh hadis.

Berdasarkan gambaran diatas, terlihat bahwa tema skripsi yang paling banyak diminati adalah naqd hadis dan figh hadis. Pada hakikatnya, kajian figh hadis tidak dapat dilepaskan dari naqd hadis. Hal tersebut terjadi karena dalam kajian teks hadis, seorang peneliti tidak diperkenankan melakukan penelitian teks hadis tanpa memastikan terlebih dahulu kualitas hadis yang ingin dikaji. Oleh sebab itu, penelitian fiqh hadis menjadi dominan dan mendapat tempat lebih dari penelitian mahasiswa yang mengkaji dalam bidang hadis.

Adapun faktor yang mendorong mayoritas mahasiswa ilmu hadis atau berkonsentrasi dalam kajian hadis memilih dalam kajiannya tentang fiqh (pemahaman) hadis pada tiga perguruan tinggi diatas adalah:

Pertama, makin berkembangnya minat mahasiswa untuk mengkaji hadishadis yang banyak dipergunakan oleh masyarakat muslim yang kadangkala diduga hadis tersebut diragukan kualitasnya untuk dijadikan landasan dalam beragama atau dalam beribadah. Secara sepintas, kandungan hadis tersebut yang terkadang menimbulkan kesan yang tidak sejalan dengan akal sehat atau hadisnya tidak begitu dikenal dikalangan para pengkaji hadis. Kondisi seperti inilah yang menarik minat mahasiswa untuk menyelidiki pemahaman hadis yang sebenarnya. Di samping itu, sebelum menyelidiki pemahaman (figh) hadis yang berkembang dalam masyarakat Islam, mahasiswa terlebih dahulu dituntut untuk mengkaji atau meneliti kualitas hadis yang akan dikaji, baik dari segi kapasistas pribadi ('adalah), kapasitas intelektual (dhabt) serta tingkat kemasyhuran mereka dalam periwayatan hadis. Dalam hal ini menelusuri kebenaran pertemuan antara satu periwayat yang menyampaikan sebuah matan hadis dengan periwayat yang menyatakan telah menerima riwayat hadis tersebut (ittishal al-sanad). Di samping memperhatikan kondisi periwayat yang demikian, para mahasiswa juga melakukan kajian mendalam terhadap para periwayat hadis untuk mengetahui tingkat keterpeliharaan dan kepercayaan rangkaian periwayat tersebut dengan tidak menyalahi periwayat yang kualitasnya lebih diakui dan tidak mengandung cacat sedikitpun.

Kedua, Berkembangnya metode pemahaman terhadap teks-teks keagamaan dan kitab suci, menjadi salah satu pendorong maraknya kajian penafsiran dan pemahaman terhadap hadis. Dalam kajian tafsir misalnya, al-Farmawi 
mengembangkan empat metode panafsiran al-Qur'an yang mencakup pada metode tahlili, muqaran, ijmali dan maudhui. Empat metode ini juga mempengaruhi dalam melakukan kajian terhadap penafsiran (fiqh) hadis.Kondisi hari ini, perkembangan pemikiran dan pergeseran pemikiran keagamaan, terutama dalam kajian al-Qur'an (Tafsir)dan Hadis (Pemahaman Hadis)tidak pernah mengenal kata usai. Selama ini al-Qur'an dan Hadis (Sunnah) telah dikaji dengan beragam metode dan diajarkan dengan aneka cara. Tuntutan agar al-Qur'an dan Hadis dapat berperan dan berfungsi dengan baik sebagai pedoman dan petunjuk hidup untuk umat manusia, terutama di zaman kontemporer ini tidak akan pernah berhenti. Oleh sebab itu, tidaklah cukup jika al-Qur'an dan Hadis dibaca atau dilombakan sebagai rutinitas belaka dalam kehidupan sehari-hari tanpa memahami maksud, mengungkap isi serta mengetahui prinsip-prinsip yang terkandung di dalamnya.

Di sisi lain, al-Qur'an dan Hadis telah diturunkan atau dikodifikasi sejak 1400 tahun yang lalu untuk merespon kondisi dan situasi sosial, politik, budaya dan relegiusitas masyarakat Arab saat itu yang tentu sangat jauh berbeda dika dibandingkan dengan kondisi dan situasi pada zaman kontemporer ini. Maka penting untuk menafsirkan dan memahami al-Qur'an dan Hadis dengan melihat dan mempertimbangkan situasi dan kondisi dimana dan kapan al-Qur'an dan Hadis diturunkan.

Berkaitan dengan masalah memahami dan menafsirkan al-Qur'an dan Hadis dalam sejarah intelektual Muslim banyak bermunculan pada tokoh di bidang penafsiran dan pemahaman al-Qur'an dan hadis, baik pada masa klasik maupun masa modern yang berusaha merumuskan dan menawarkan berbagai metodologi untuk menafsirkan dan memahami al-Qur'an dan Sunnah yang dianggap baik dan tepat. Dari sinilah kemudian muncul berbagai teori, gagasan, konsep dan disiplin keilmuan yang khusus merespon diskursus pemahaman hadis atau penafsiran alQur'an ini, satu dianataranya adalah hermeneutika. Untuk itu, dengan adanya perkembangan metodologi kajian ini, memberikan semangat dan ketertarikan bagi mahasiswa dalam melakukan kajian dan penelitian terhadap pemahaman hadis (figh hadis)

Ketiga, banyaknya upaya pendigitalisasian buku-buku atau kitab-kitab referensi hadis dan ilmu hadis, baik yang memuat matan hadis, periwayat hadis, maupun syarh hadis. Hal ini memberikan kemudahan kepada bagi mahasiswa yang hendak melakukan kajian atau penelitian terhadap hadis.

Keempat, besarnya minat di kalangan umat Islam secara umum untuk mempertanyakan praktek-praktek keagamaan mereka kepada tokoh agama, baik melalui media elektronik, media cetak, maupun dalam ceramah-ceramah keagamaan, baik di masjid maupun di majlis-majlis ilmu lainnya. Pertanyaanpertanyaan yang mereka ajukan berdasarkan apa yang mereka dengar di berbagai majelis tersebut, terkadang menyisakan banyak pertanyaan yang tidak atau belum sempat terakomodir karena keterbatasan tempat dan waktu. Pertanyaan tersebut banyak yang terkait dengan pemahaman-pemahaman hadis nabi, yang pada gilirannya menjadi perhatian para pengkaji hadis, dalam hal ini mahasiswa di bidang hadis untuk melakukan kajian lebih mendalam terhadap hadis-hadis tersebut dalam bentuk penelitian hadis (matan).

Tema Kajian Hadis Akademik Prodi IImu Hadis UIN Raden Fatah Tema Kajian Hadis UIN Raden Fatah Palembang

\begin{tabular}{|l|l|c|c|c|c|c|c|}
\hline \multirow{2}{*}{ No } & \multirow{2}{*}{ Tahun } & \multirow{2}{*}{$\begin{array}{c}\text { Jumlah } \\
\text { Skripsi }\end{array}$} & \multicolumn{5}{|c|}{ Tema Kajian Fiqh Hadis } \\
\cline { 4 - 8 } & & Aqidah & Ibadah & Akhlak & Syari'ah & Mu'amalah \\
\hline 1 & 1995 & - & - & - & - & - & - \\
\hline
\end{tabular}




\begin{tabular}{|l|l|l|l|l|l|l|l|}
\hline 2 & 1996 & 1 & - & - & - & - & 1 \\
\hline 3 & 1997 & 3 & - & 1 & - & 1 & 1 \\
\hline 4 & 1998 & 1 & 1 & - & - & - & - \\
\hline 5 & 1999 & 3 & 1 & 2 & - & - & - \\
\hline 6 & 2000 & 4 & 1 & - & - & - & 3 \\
\hline 7 & 2001 & 2 & - & - & - & - & 2 \\
\hline 8 & 2002 & 2 & - & - & - & 1 & 1 \\
\hline 9 & 2003 & 3 & 1 & - & - & 2 & - \\
\hline 10 & 2004 & 12 & 2 & 1 & - & 9 & - \\
\hline 11 & 2005 & 5 & 1 & - & - & 4 & - \\
\hline 12 & 2006 & - & - & - & - & - & - \\
\hline 13 & 2007 & - & - & - & - & - & - \\
\hline 14 & 2008 & 4 & 1 & 3 & - & - & - \\
\hline 15 & 2009 & 3 & 1 & - & - & 2 & - \\
\hline 16 & 2010 & 1 & - & - & - & 1 & - \\
\hline 17 & 2011 & 7 & 1 & 1 & & 3 & 2 \\
\hline 18 & 2012 & 10 & - & 5 & 1 & 3 & 1 \\
\hline 19 & 2013 & 12 & - & 4 & 2 & 5 & 1 \\
\hline 20 & 2014 & 3 & - & - & 1 & 1 & 1 \\
\hline 21 & 2015 & 7 & 1 & 1 & 1 & 4 & - \\
\hline 22 & 2016 & 4 & - & 2 & 1 & 2 & - \\
\hline Jumlah & 64 & 11 & 20 & 6 & 38 & 13 \\
\hline
\end{tabular}

Berdasarkan pada tabel di atas, tema kajian fiqh hadis tentang kajian aqidah sebanyak 11 skripsi, 20 skripsi yang membahas tema ibadah, 6 skripsi melakukan kajian hadis tentang akhlak, 38 skripsi mahasiswa yang tertarik mengkaji syari'ah dan 13 skripsi mahasiswa yang membahas tentang mu'amalah.

Dominasi kajian fiqh hadis aspek syari'ah dan ibadah dari skripsi mahasiswa ilmu hadis rentang tahun 1995 - 2016 memiliki alasan akademik yang perlu di jadi perhatian khusus bagi para pengkaji hadis. Alasan tersebut diantaranya adalah:

Pertama, adanya kecenderungan yang berkembang dalam kehidupan beragama masyarakat Islam tentang kepastian hukum terhadap segala bentuk aktivitas keagamaan. Masyarakat membutuhkan kepastian hukum terhadap segala bentuk pemikiran dan praktek yang dilakukan masyarakat dan umat Islam. Dari sinilah para mahasiswa Tafsir Hadis, terutama yang mengkaji dalam bidang hadis merasa tertarik untuk menelusuri lebih jauh dalam bentuk penelitian berupa skripsi dengan harapan bisa mencari jawaban atas pemikiran-pemikiran dan praktek keagamaan yang sudah berkembang dalam masyarakat Islam untuk mencari status hukumnya.

Kedua, dari aspek dominasi kajian skripsi mahasiswa ilmu hadis tentang ibadah ini merupakan imbas dari alasan pertama, yaitu adanya tuntut kepastian hukum yang berkembang dalam kehidupan beragama masyarakat yang kemudian berhubungan langsung dengan aspek ibadah. Setiap ibadah yang dilaksanakan, selalu berhubungan dengan aspek hukum atau kepastian hukumnya. Maka dari itu, para pengkaji hadis dari mahasiswa IImu Hadis tertarik untuk mengkaji aspek ibadah yang menjadi pusat kajian mereka dalam bentuk skripsi atau tugas akhir.

Tema Kajian Hadis Akademik UIN Syarif Kasim Pekanbaru

\begin{tabular}{l|l|l|l} 
No & Tahun & Jumlah & Tema Kajian Fiqh Hadis \\
\hline
\end{tabular}




\begin{tabular}{|l|l|c|c|c|c|c|c|}
\hline & & Skripsi & Aqidah & Ibadah & Akhlak & Syari'ah & Mu'amalah \\
\hline 1 & 1995 & - & - & - & - & - & - \\
\hline 2 & 1996 & - & - & - & - & - & - \\
\hline 3 & 1997 & 1 & - & - & 1 & - & - \\
\hline 4 & 1998 & - & - & - & - & - & - \\
\hline 5 & 1999 & 1 & - & - & - & 1 & - \\
\hline 6 & 2000 & - & - & - & - & - & - \\
\hline 7 & 2001 & - & - & - & - & - & - \\
\hline 8 & 2002 & - & - & - & - & - & - \\
\hline 9 & 2003 & - & - & - & - & - & - \\
\hline 10 & 2004 & - & - & - & - & - & - \\
\hline 11 & 2005 & 3 & - & 2 & 1 & - & - \\
\hline 12 & 2006 & - & - & - & - & - & - \\
\hline 13 & 2008 & 2 & - & 1 & - & 1 & - \\
\hline 14 & 2009 & - & - & - & - & - & - \\
\hline 15 & 2010 & - & - & - & - & - & - \\
\hline 16 & 2011 & - & - & - & - & - & - \\
\hline 17 & 2012 & 6 & - & 5 & - & - & 1 \\
\hline 18 & 2013 & 7 & 1 & 2 & 1 & 2 & 1 \\
\hline 19 & 2014 & 6 & - & 3 & - & - & 3 \\
\hline 20 & 2015 & 13 & 1 & 6 & 1 & 3 & 2 \\
\hline Jumlah & 39 & 2 & 19 & 4 & 7 & 7 \\
\hline & & & & & & & \\
\hline
\end{tabular}

Dalam kajian hadis akademik di Universitas Islam Negeri Syarif Kasim Pekanbaru, bila dilihat dari sisi model kajian yang sudah disebutkan pada bagian terdahulu, maka skripsi mahasiswa yang paling dominan mengkaji dari sisi fiqh hadis. Dalam pada itu, bila ditelusuri lebih jauh, maka tema kajian figh hadis yang menjadi populer dari skripsi mahasiswa IImu Hadis atau kecenderungan dalam kajian hadis adalah masalah ibadah.

Berdasarkan pada tabel di atas, tema kajian fiqh hadis tentang kajian aqidah sebanyak 2 skripsi, 19 skripsi yang membahas tema ibadah, 4 skripsi melakukan kajian hadis tentang akhlak, 7 skripsi mahasiswa yang tertarik mengkaji syari'ah dan 7 skripsi mahasiswa yang membahas tentang mu'amalah.

Tema Kajian Hadis Akademik UIN Imam Bonjol Padang

\begin{tabular}{|l|l|c|c|c|c|c|c|}
\hline \multirow{2}{*}{ No } & \multirow{2}{*}{ Tahun } & \multirow{2}{*}{\begin{tabular}{c} 
Jumlah \\
\cline { 4 - 8 }
\end{tabular}} & & \multicolumn{5}{|c|}{ Tema Kajian Fiqh Hadis } \\
\cline { 5 - 8 } & & Aqidah & Ibadah & Akhlak & Syari'ah & Mu'amalah \\
\hline 1 & 1993 & 1 & - & - & - & 1 & - \\
\hline 2 & 1994 & 1 & 1 & - & - & - & - \\
\hline 3 & 1995 & 2 & - & 1 & - & 1 & - \\
\hline 4 & 1996 & 1 & 1 & - & - & - & - \\
\hline 5 & 2000 & 4 & 1 & 1 & - & 1 & 1 \\
\hline 6 & 2001 & 4 & - & 1 & - & - & 3 \\
\hline 7 & 2002 & 4 & 2 & 1 & - & 1 & - \\
\hline 8 & 2003 & 6 & 2 & 1 & - & 1 & 2 \\
\hline 9 & 2004 & 3 & - & 2 & - & - & 1 \\
\hline 10 & 2005 & 3 & - & - & - & 2 & 1 \\
\hline 11 & 2006 & 1 & - & 1 & - & - & - \\
\hline
\end{tabular}




\begin{tabular}{|l|l|l|l|l|l|l|l|}
\hline 12 & 2007 & 4 & - & 2 & - & 2 & - \\
\hline 13 & 2008 & 3 & - & - & - & 1 & 2 \\
\hline 14 & 2009 & 3 & - & 1 & - & 1 & 1 \\
\hline 15 & 2011 & 1 & 1 & - & - & - & - \\
\hline 16 & 2012 & 2 & 1 & - & - & 1 & - \\
\hline 17 & 2014 & 12 & 1 & 5 & - & 3 & 3 \\
\hline 18 & 2015 & 7 & - & 1 & - & 6 & - \\
\hline 19 & 2016 & 6 & - & 4 & - & 2 & - \\
\hline 20 & 2017 & 2 & - & - & - & 2 & - \\
\hline \multicolumn{2}{|l|}{ Jumlah } & & 10 & 21 & 0 & 25 & 14 \\
\hline
\end{tabular}

Studi hadis di Perguruan Tinggi Agama Islam (PTAI) Indonesia memiliki pola, ragam dan karakteristik sesuai dengan kekhasan masing-masing. Berbagai jenis dan bentuk mata kuliah yang tawarkan dalam studi hadis menandakan adanya dinamika yang berkesinambungan. Studi hadis tidak selalu identik dengan ilmu hadis atau hadis, akan tetapi studi ini sudah mengikuti arus perkembangan dan tuntutan zaman dimana arus teknologi yang menghasilkan adanya transformasi ilmu pengetahuan ke berbagai belahan dunia menyebabkan pemahaman yang segar terhadap kajian hadis ${ }^{6}$.

Dalam kajian hadis akademik di Universitas Islam Negeri Imam Bonjol Padang, bila dilihat dari sisi model kajian yang sudah disebutkan pada bagian terdahulu, maka skripsi mahasiswa yang paling dominan mengkaji dari sisi fiqh hadis. Dalam pada itu, bila ditelusuri lebih jauh, maka tema kajian figh hadis yang menjadi populer dari skripsi mahasiswa IImu Hadis atau kecenderungan dalam kajian hadis adalah masalah syari'ah.

Berdasarkan pada tabel di atas, tema kajian fiqh hadis tentang kajian aqidah sebanyak 10 skripsi, 21 skripsi yang membahas tema ibadah, 0 skripsi melakukan kajian hadis tentang akhlak, 25 skripsi mahasiswa yang tertarik mengkaji syari'ah dan 14 skripsi mahasiswa yang membahas tentang mu'amalah.

\section{Metodologi Analisis Kajian Hadis Akademik UIN Raden Fatah Palembang, UIN Syarif Kasim Pekanbaru dan UIN Imam Bonjol Padang}

Sebagaimana disajikan dalam pembahasan sebelumnya, bahwa tema-tema utama dari seluruh skripsi hadis yang ditemukan, dapat dikategorikan dalam lima besar yaitu ilmu mushthalah hadis, kritik (naqd), pemahaman (fiqh) hadis, kajian kitab hadis dan pemikiran atau tokoh hadis. Bahasan berikut adalah merunut analisis metodologi skripsi mahasiswa hadis berdasarkan pilihan-pilihan tema yang mereka fokuskan.

Pertama, secara tematis, pilihan mahasiswa hadis dalam memilih judul skripsi yang terkait dengan ilmu mushthalah hadis lumayan variatif. Kecenderungan pemilihan judul tidak menunjukkan keragaman yang signifikan, meskipun terlihat bahwa dari UIN Raden Fatah Palembang 22 judul yang masuk dalam kategori ini, 29 berkutat pada metodologi kritik hadis dalam upaya penentuan keshahihan sebuah hadis, jarh wa ta'dil periwayat hadis, keadilan sahabat serta perbincangan seputar

${ }^{6}$ Alfatih Suryadilaga, Ragam Studi Hadis di PTKIN Indonesia dan Karakteristinya: Studi atas Kurikulum IAIN Bukittinggi, IAIN Batu Sangkar, UIN Suna Kalijaga dan IAIN Jember, (Jakarta: JJournal of Qur'an and Hadits,: 2015), h. 217 
kehujjahan hadis-hadis tertentu dalam hal ini hadis mursal. UIN Syarif Kasim terdapat 16 judul dalam mushthalah hadis dan 52 judul dalam kritik hadis serta UIN Imam Bonjol Padang terdapat 16 judul dalam kajian mushthala dan 9 judul kategori kritik hadis

Bila diperhatikan secara seksama pemilihan judul skripsi dalam kategori ilmu mushthalah hadis ini, kecenderungan untuk memilih tema-tema terkait dengan pemahaman hadis dapat difahami. Tidak saja karena pemahamanhadis berindikasi pada kemampuan praktis menghidupkan hadis dalam keseharian, tetapi juga metodologi pemahaman hadis yang ditemukan dapat berimplikasi pada aspek legalistik normatif. Secara praktis, menelusuri metodologi pemahaman umat atau organisasi keislaman terhadap hadis relatif lebih memungkinkan untuk dilakukan dibanding menggali literatur-literatur tentang bahasan-bahasan keilmuan mushthalah hadis yang masih banyak tersaji dalam bahasa asing dalam hal ini bahasa Arab.

\begin{tabular}{|l|l|c|c|c|c|c|c|}
\hline \multirow{2}{*}{ No } & \multicolumn{2}{|c|}{ Perguruan Tinggi } & \multirow{2}{*}{$\begin{array}{c}\text { Jumlah } \\
\text { Skripsi } \\
\text { Hadis }\end{array}$} & \multicolumn{5}{|c|}{ Model Kajian } \\
\cline { 5 - 9 } & & Mushthalah & Naqd & Fiqih & Kitab & Tokoh \\
\hline 1 & $\begin{array}{l}\text { UIN Raden Fatah } \\
\text { Palembang }\end{array}$ & 143 & 22 & 29 & 64 & 12 & 16 \\
\hline 2 & $\begin{array}{l}\text { UIN Syarif Kasim } \\
\text { Pekanbaru }\end{array}$ & 123 & 16 & 52 & 37 & 1 & 17 \\
\hline 3 & $\begin{array}{l}\text { UIN Imam Bonjol } \\
\text { Padang }\end{array}$ & 99 & 16 & 9 & 69 & 1 & 4 \\
\hline
\end{tabular}

Kedua, secara metodologis, pemilihan mahasiswa hadis terhadap tema-tema kajian naqd hadis mengikuti pola yang hampir seragam. Pemilihan langkah-langkah metodologis penelitian hadis yang dilakukan mahasiswa UIN Raden Fatah Palembang, UIN Syarif Kasim Pekanbaru dan UIN Imam Bonjol Padang senantiasa mengikuti pola yang diajarkan oleh M. Syuhudi Ismail baik yang tersaji dalam bukunya Kaedah Keshahihan Sanad Hadis maupun yang secara spesifik menguraikan metodologi Penelitian Hadis. Kedua karya M. Syuhudi Ismail ini merupakan buku wajib bagi para peminat kajian hadis yang pada gilirannya berimplikasi sikap mahasiswa untuk merujuk secara rigid kepada kedua buku tersebut. Sikap ini dapat dimaklumi karena di samping cara penyajiannya yang praktis dan informatif, langkah-langkah penelitian yang disajikan pun mudah dicerna dan diikuti.

Hanya saja, dalam prakteknya, langkah-langkah penelitian yang dilakukan oleh mahasiswa banyak mengalami penyederhanaan. Contoh kasus yang dapat diuraikan disini adalah pilihan metode takhrij hadis. Ada mahasiswa lebih cenderung menerapkan satu atau dua metode takhrij dalam menelusuri hadis-hadis yang mereka kaji, dalam hal ini metode takhrij dengan menggunakan salah satu lafaz dari matan hadis dan atau berdasarkan tema atau topik tertentu. Sedangkan metode takhrij yang lain, sangat jarang ditemukan dalam karya-karya skripsi mahasiswa hadis.

Ketiga, dalam kajian metodologis terhadap pemahaman (fiqh)hadis, secara umum mahasiswa menggunakan tiga teknik interpretasi sebagai cara kerja dalam memahami makna hadis. Ketiga teknik interpretasi tersebut adalah sebagai berikut: 1) Interpretasi Tekstual.Interpretasi tekstual merupakan pemahaman terhadap matan hadis berdasarkan teksnya semata, baik yang diriwayatkan secara lafal maupun yang diriwayatkan secara makna dan atau memperhatikan bentuk dan cakupan 
makna. Teknik interpretasi tekstual cenderung mengabaikan pertimbangan latar belakang peristiwa hadis dan dalil-dalil lainnya. Untuk teknik interpretasi tekstual dapat dilakukan pendekatan linguistik, teologi normatif dan teleologis. 2) Interpretasi Intertekstual. Teknik interpretasi ini sering juga disebut dengan teknik munasabah, yaitu teknik interpretasi terhadap narasi hadis dengan memperhatikan sistematika matan hadis yang dikaji, atau hadis lain yang semakna, dan atau memperhatikan ayat al-Qur'an yang memiliki keterkaitan. Teknik ini dipergunakan dengan dasar bahwa hadis yang merupakan rangkaian atau memiliki keterkaitan dengan hadis yang lain. Pemahaman terhadap suatu hadis tidak dapat dilepaskan dengan kandungan hadis yang lain dan atau ayat al-Qur'an. Hal ini mempertegas keberadaan dan fungsi hadis tersebut sebagai penjelas terhadap ayat-ayat alQur'an. Penggunaan teknik interpretasi ini dapat disandingkan dengan pendekatan teologi-normatif. 3) Interpretasi Kontekstual. Teknik interpretasi ini lebih mengedepankan pada pemahaman narasi hadis dengan memperhatikan asbab alwurud al-hadis, yaitu latar belakang lahirnya hadis yang dimaksud. Dengan penerapan teknik ini, upaya interpretasi hadis Nabi dibarengi dengan kajian yang mendalam seputar kondisi faktual saat hadis tersebut dinarasikan, siapa saja yang terlibat di dalamnya, dimana penarasiannya itu terjadi, dan pada kondisi apa penarasian itu terjadi. Kondisi faktual masa penafsiran itu juga tidak menafikan pelibatan konteks kekinian. Pada gilirannya, interpretasi yang dilakukan dapat menyajikan dua sisi kondisi yang diinginkan sehingga interpretasi dapat aplikatif. Untuk menerapkan teknik interpretasi ini, pendekatan holistik dan multidisipliner akan sangat membantu, di samping pendekatan-pendekatan keilmuan lainnya seperti pendekatan historis, sosiologis, semiotik dan sebagainya. Seluruh teknik interpretasi ini umum diterapkan dalam setiap penulisan skripsi yang menjadikan pemahaman (figh) hadis sebagai tema sentral kajian mereka, sehingga hampir tidak ditemukan preferensi mahasiswa hadis diatas salah satu teknik interpretasi dibanding teknik interpretasi lain.

Keempat, Kajian kitab hadis sangat kurang ditemukan dalam karya skripsi mahasiswa. Skripsi Mahasiswa UIN Raden Fatah Palembang ditemukan 12 kajian kitab, UIN Syarif Kasim Pekanbaru 1 kajian dan UIN Imam Bonjol 1 kajian. Rendahnya minat mahasiswa untuk melakukan kajian kitab ini bukanlah karena kitab hadis tidak menarik untuk dibahas, akan tetapi lebih pada kendala bahasa, dimana hampir seluruh kitab hadis sumber dan ilmu hadis atau kitab-kitab pendamping tersedia dalam bahasa Arab. Faktor bahasa menjadi kendala utama dalam upaya pengkajian terhadap kitab-kitab hadis.

Kelima, Kajian pemikiran atau tokoh hadis dalam skripsi mahasiswa juga masih sangat sedikit. Skripsi UIN Raden fatah Palembang ditemukan hanya 16 kajian, UIN Syarif Kasim Pekanbaru 17 kajian dan UIN Imam Bonjol Padang 6 kajian. Jumlah yang sangat sedikit tersebut tidak berimbang bila dibandingkan dengan banyaknya tokoh hadis atau pengkaji hadis yang patut untuk dijadikan bahan kajian.

\section{E. Rekomendasi Arah Kajian Hadis ke Depan}

Berdasarkan hasil kajian dari pemetaan skripsi mahasiswa Tafsir Hadis UIN Raden Fatah Palembang, UIN Syarif kasim Pekanbaru dan UIN Raden Fatah Palembang, sebagai rekomendasi dari penelitian ini adalah perlu ada studi lain atau kajian lain dalam penulisan skripsi yang dilakukan mahasiswa ilmu hadis terutama pada kajian hadis yang membahas dari berbagai tema dalam konteks ke-Indonesiaan atau studi kajian Hadis Islam Melayu. Rekomendasi ini didasarkan pada; 
Pertama, masih minimnya skripsi mahasiswa Tafsir Hadis (Ilmu Hadis) dalam mengkaji perkembangan pemikiran hadis di Melayu-Nusantara, padahal para ulamaulama dari Melayu Nusantara mempunyai peran yang sangat penting dalam mengembangkan kajian keislaman di Melayu-Nusantara, terutama dalam Tafsir dan penyebaran Sunnah. Di samping itu, masih banyaknya buku-buku atau kitab-kitab karya ulama Melayu-Nusantara yang belum dikaji secara akademik sebagai bahan pertimbangan dalam perkembangan pemikiran keislaman di Melayu-Nusantara

Kedua, Di samping itu, perlu ada pengembangan kajian hadis, terutama dalam integrasi ilmu dari berbagai disiplin ilmu (interdisipliner) yang terkoneksi dengan kajian hadis. Memasuki era modern, umat Islam mulai bersentuhan dengan perkembangan baru dalam berbagai aspek kehidupan, seperti rasionalisme dan nasionalisme, dan perubahan sosial budaya. Anomali semakin terasa ketika umat Islam memasuki era globaliasasi dan informasi yang membawa berbagai gagasan seperti demokrasi, pluralisme, dan HAM. Dalam lingkungan masyarakat global ini, umat Islam tidak bisa lagi hidup ekslusif, monolitis, dan diskriminatif. Ajaran Sunnah dalam hadīs yang dibangun atas dasar epistemologi era klasik (teosentris, negara teologis, homogen, ekslusif) tentu banyak menghadapi persoalan ketika dihadapkan pada kasus atau gagasan baru yang dibangun atas dasar epistemologi moderen. Apalagi saat pemikiran tersebut lebih didominasi pola pikir pragmatis yang tegak di atas fondasi positivisme yang anti metafisis. Di sini nilai-nilai ajaran Sunnah ditantang untuk memberikan solusi yang logis-rasional namun tetap orisinal, sehingga Islam tidak dituding sebagai agama yang mengajarkan kekerasan, teror dan diskriminatif.

\section{F. Kesimpulan}

Setelah melakukan kajian dan pembahasan terhadap peta kajian hadis akademik di UIN Raden Fatah Palembang, UIN Syarif Kasim Pekanbaru dan UIN Imam Bonjol Padang terjadi keunikan kajian hadis dari masing-masing perguruan tinggi, maka penulis memberikan kesimpulan bahwa model kajian hadis yang paling dominan dalam penulisan skripsi mahasiswa UIN Raden Fatah Palembang dan UIN Imam Bonjol Padang adalah figh hadis. Sedangkan UIN Syarif Kasim Pekanbaru lebih cenderung pada kritik hadis (naqd al-hadis). Dominasinya kajian ini disebabkan adanya realitas akademik dari masing-masing perguruan tinggi yang dipengaruhi sosial keagamaan masyarkat Islam setempat dan faktor dosen yang memberikan arahan pada masing-masing mahasiswa. Sedangkan tema kajian skripsi yang paling diminati oleh mahasiswa UIN Raden fatah Palembang dan UIN Imam Bonjol adalah masalah syari'ah, berbeda dengan UIN Syarif Kasim Pekanbaru, lebih cendering pada tema hadis-hadis ibadah. Adapun metodologi kajian kajian hadis akademik yang digunakan para mahasiswa dalam melakukan penelitian hadis adalah tekstual, intertekstual dan kontekstual. 


\section{DAFTAR PUSTAKA}

Abu Rayyah, Mahnûd. Adhwâ' ‘ala al-Sunnat al-Muhammadiyyat aw Difâ' 'an alHadîs. Dar al-Makrifah. Mesir. t.th. cet. III.

Abu Yasir, al-Hasan al-'Ilmiy. Fiqh al-Sunnat al-Nabawiyyah Dirayah wa Tanzîlan.

Al-'Azhamiy, Muhammad Musthafa.Manhaj al-Naqd inda al-Muhaddisin, Nasy'atun wa tarikuhu. Maktabat al-Kausar. Riyadh. 1990.

al-Adlabi, Salahuddin bin Ahmad.Manhaj Naqil Matn.Dar al-Afaq al-Jadidah. Beirut. 1403 H./ 1983 M

Al-Asqalani, Ahmad bin Alī bin Hajar. Nuzhatun Nazar Syarh Nukhbah al-Fikr, Maktabah al-Munawwar. Semarang. t.th.

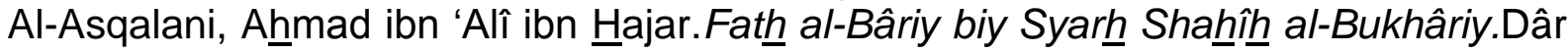
al-Fikr. Beirut. $1414 \mathrm{H} / 1993 \mathrm{M}$.

Al-Bukhari, Abû 'Abd Allah Muhammad ibn Ismâ'îl ibn Ibrâhîm ibn Bardizbah alJa'fiy.al-Jâmi' al-Shahih al-Musnad al-Mukhtashar min Hadis Rasul Allah Shalla Allah Alayh wa Sallama wa Sunanih wa Ayyâmih. Dâr lbn Kasîr. Beirut.1407H/1987 M. Cet. 3.

Ali, Nizar. Memahami Hadis Nabi (Metode dan Pendekatan). CESaD YPI AlRahmah: Yogyakarta. 2001.

Al-Khatib, Muhammad 'Ajjaj.Ushul al-Hadis;' 'Ulumuh wa Musthalahuh. Dar al-Fikr. Beirut.1409 H / 1989 M

Al-Nasai, Abu 'Abd al-Rahmân Ahmad ibn Syu'ayb ibn 'Alî ibn Bahr ibn Sinan. Sunan al-Nasâ'iy biy Syarh ă al-Suyûthiy wa biy Hasiyât al-Sindiy. Dar al- $\underline{\text { Hadîs. }}$ Kairo. $1407 \mathrm{H} / 1987 \mathrm{M}$

Al-Nawawi, Abu Zakariyâ Yahyya ibn Syarf. Shaḥîh Muslim biy Syarh al-Nawâwiy. alMathba'at al-Mishriyyah. Mesir. 1924

Al-Shidiqie, T.M Hasbie.Sejarah Perkembangan Hadis. Bulan Bintang. Jakarta. 1973

Al-Siba'iy, Muhammad Musthafa.al-Sunnah wa Makanatuha fiy al-Tasyri' al-lslamiy. Maktabah Dar al-'Arubah. Kairo. 1380 H/1961 M. Cetakan I

Al-Suyuthiy, Jalal al-Din. Tadrib al-Rawi 'ala Taqrib al-Nawawi. Dar al-Kutub alHaditsah. T.tp. t.th. Juz II

Al-Tirmizi, Muhammad ibn 'Îsa Abû 'Îsa al-Salamiy. al-Jâmi' al-Shahîh $\underline{h}$ Sunan alTurmudziy. Tahqîq Angmad Muhammad Syâkir. Dar al-Turâs al-'Arabiy. Beirut. t.th.

Al-Umri, Muhammad Ali Qasim. Dirâsât fi Manhaji An-Naqdi 'Indal Muhadditsîn.Dar An-Nafais. Yordan. 2000.

Buchari M.Metode Pemahaman Hadis: Sebuah Kajian Hermeneutik. Nuansa Madani. Jakarta. 1999.

Bustamin, dkk.Metodologi Kritik Hadis.Raja Grafindo Persada. Jakarta. 2004.

Farid, Ahmad.60 Biografi Ulama Salaf, Penerjemah;Masturi Irham \& Asmu'l Taman.Pustaka Al-Kautsar. Jakarta. 2006

Hamadah, 'Abbas Mutawalli. al-Sunnah al-Nabawiyyah wa Makanatuha fi Tasyri'. Dar al-Qaumiyyah: Kairo. 1965.

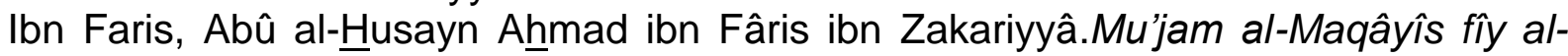
Lughah.Tahqiq Syihâb al-Dîn Abû 'Amrû. Dâr al-Fikr. Beirut. 1415 H/1994 M. cet.l. 
Ibn Manzhur, Muhammad.Lisan al-Arab. Dâr al-Turas al-'Arabiy wa Mu'assasat alTarikh al-'Arabiy. Beirut. 1412 H / 1992 M. J. VII.

Ismail, Muhammad Syuhudi. Metodologi Penelitian Hadis Nabi. Bulan Bintang. Jakarta. 1997.

Ismail, Muhammad Syuhudi. Pengantar IImu Hadis. Angkasa. Bandung. 1991

Ismail, Muhammad Syuhudi.Hadis Nabi Yang Tekstual dan Kontekstual. Bulan Bintang. Jakarta. 1994

Itr, Nûr al-Dîn.Manhaj al-Naqd fiy 'Ulûm al-ㅌadîs. Dar al-Fikr. Damaskus. 1418 H / $1997 \mathrm{M}$.

Jumantoro, Totok. Kamus IImu Hadist. PT. Bumi Aksara. Jakarta. 2002.

Munawir, Ahmad Warson.al-Munawwir Kamus Arab-Indonesia. Pustaka Progresif. Surabaya. 1997)

Noor, Muhibbin.Kritik Kesahihan Hadis Imam Bukhari : Telaah Kritis atas Kitab alJâmi' al-Shahîh, Waqtu. Yogyakarta. 2003

Poerwadarminta, W.J.S. Kamus Umum Bahasa Indonesia. Balai Pustaka. Jakarta. 1985

Prodi IImu Hadis, Pedoman Akademik Prodi IImu Hadis Fakultas Ushuluddin dan

Pemikiran Islam

Prodi IImu Hadis. Pedoman Akademik Prodi IImu Hadis Fakultas Ushuluddin dan Pemikiran Islam. Noer Fikri. Palembang. 2016.

Salamah, Muhammad Khalâf.Lisân al-Muhaddisîn - Mu'jâm - Yu'niy bi Syurûh Mushthalahât al-Munhaddisînal-Qādîmah wa al-Hadîsah wa Rumûzuhum wa Isyarâtuhum wa Jumlat min Musykil 'Ibârâtihim wa Gharîb Tarâkîbihim w Anâdir Asâlibihim. (DVD Maktabah al-Syâmilah) edisi II, J. III.

Shalih, Subhi,Ulum al-Hadits wa Mushthalahuhu.Dar al-'Ilm li al-Malayin. Beirut. 1977 Smeer, Zeid B. Ulumul Hadis, Pengantar Studi Hadis Praktis.UIN-Malang Press. Malang. 2008

Sumbulah, Umi.Kritik Hadis; Pendekatan Historis Metodologis.UIN-Malang Press. Malang. 2008.

Suparta. Munzier. IImu Hadits.PT. Raja Grafindo Persada. Jakarta. 2008

Suryadilaga, Muhammad Alfatih. Ragam Studi Hadis di PTKIN Indonesia dan Karakteristinya: Studi atas Kurikulum IAIN Bukittinggi, IAIN Batu Sangkar, UIN Suna Kalijaga dan IAIN Jember. Journal of Qur'an and Hadits. Jakarta. 2015

Suryadilaga, Muhammad Alfatih.Aplikasi Penelitian Hadis dari Teks ke Konteks. Teras. Yogyakarta. 2009.

Suryadilaga, Suryadi dan Muhammad Alfatih. Metodologi Penelitian Hadis. T-H Press. Yogyakarta. 2009.

Sya'rani, Usman. Otentisitas Hadis Menurut Ahli Hadis dan Kaum Sufi. Pustaka Firdaus. Jakarta. 2002.

Thahhan, Mahmud. Taisir Mushthalahul Hadits.Dar Al-Fikr. Beirut. t.t.

Wahid, Ramli Abdul.Studi IImu Hadits. Cita Pustaka Media. Bandung. 2005.

Ya'qub, Ali Mustafa. Kritik Hadits. Pustaka Firdaus. Jakarta. 2008.

Yunus, Mahmud. Kamus Arab-Indonesia. Mahmud Yunus Wadzuriyah. Jakarta. t.th.

Yuslem, Nawir. Ulumul Hadis. Mutiara Sumber Widya. Jakarta. 2001. 